\title{
Mesozooplankton selective feeding in subtropical coastal waters as revealed by HPLC pigment analysis
}

\author{
Hongbin Liu ${ }^{1,2, *}$, Mianrun Chen ${ }^{1}$, Koji Suzuki ${ }^{3}$, Chong Kim Wong ${ }^{4}$, \\ Bingzhang Chen ${ }^{2}$ \\ ${ }^{1}$ Department of Biology, Hong Kong University of Science and Technology, Clear Water Bay, Hong Kong \\ ${ }^{2}$ Atmospheric, Marine, and Coastal Environment (AMCE) Program, Hong Kong University of Science and Technology, \\ Clear Water Bay, Hong Kong \\ ${ }^{3}$ Faculty of Environmental Earth Science, Hokkaido University, North 10 West 5, Kita-ku, Sapporo 060-0810, Japan \\ ${ }^{4}$ Department of Biology, The Chinese University of Hong Kong, Shatin, New Territories, Hong Kong
}

\begin{abstract}
Phytoplankton community composition and mesozooplankton selective feeding on different phytoplankton taxa were studied by HPLC pigment analysis at 2 sites with contrasting hydrography in the coastal areas of Hong Kong. The site (WE) on the western part of Hong Kong is located in the Pearl River estuary, whereas the site (EO) on the eastern part of Hong Kong is influenced by oceanic waters. Despite the strong difference in hydrographic conditions, diatoms were the dominant phytoplankton at both sites throughout most months of the year, contributing on average more than $40 \%$ of the total phytoplankton in terms of chlorophyll a ( $\mathrm{chl} \mathrm{a}$ ). Cryptophytes were the second most abundant phytoplankton group at both sites, whereas contributions from haptophytes, green algae, cyanobacteria and dinoflagellates were small. Diatoms and cryptophytes, the 2 most dominant phytoplankton groups, accounted for about 80 and $75 \%$ of the diets of mesozooplankton at EO and WE, respectively. One consistent pattern observed throughout the study period was that mesozooplankton assemblages strongly preferred dinoflagellates over other types of phytoplankton, especially in estuarine waters, even though dinoflagellates only contributed to a small fraction of total chl a. On the other hand, phytoplankton groups with relative small cell sizes, such as green algae and cyanobacteria, were not efficiently ingested. Overall, mesozooplankton feeding selectivity in subtropical eutrophic coastal waters, where planktonic food is sufficient, appears to be influenced by a combination of different factors, including the compositions of predators and the size and quality of the prey.
\end{abstract}

KEY WORDS: Mesozooplankton herbivory · HPLC pigment analysis · CHEMTAX · Feeding selectivity

Resale or republication not permitted without written consent of the publisher

\section{INTRODUCTION}

Zooplankton grazing is an important source of phytoplankton mortality in the sea. Although, on average, mesozooplankton are not the most important consumers of phytoplankton (Calbet 2001), they have been known to consume almost all primary production in some special environments, such as the frontal zone of river plumes (Liu \& Dagg 2003, Fielding et al. 2007), productive coastal waters (Kiørboe 1993) and cyclonic cold-core eddies (Landry et al. 2008). More importantly, mesozooplankton may exert an indirect effect on phytoplankton production and composition as predators of microzooplankton (Landry et al. 1993, Liu et al. 2005a). The overall effect of mesozooplankton grazing is to shift phytoplankton community structure toward small cells through direct ingestion of large cells and reduced mortality of small phytoplankton 
through a trophic cascade, a mechanism that counterbalances the microzooplankton grazing pressure, which is usually higher on pico- and nanophytoplankton than on microphytoplankton (Strom et al. 2007, Dagg et al. 2009).

It is well established that, in addition to environmental variables, food concentration, size and quality affect copepod feeding rate (Harris 1996). There has been a growing number of studies on copepod dietary diversity, omnivory and selective feeding (e.g. Kleppel 1993, Harris 1996, Meyer-Harms et al. 1999, Stevens et al. 2004). In recent years, several studies have been made on the taxa-specific rates of phytoplankton growth and microzooplankton grazing using a combination of the dilution method and HPLC pigment analysis (e.g. Latasa et al. 1997, Suzuki et al. 2002b, Obayashi \& Tanoue 2002). This technique has also been applied to study the selective nature of copepod and mesozooplankton herbivory (Kleppel et al. 1988, Head \& Harris 1994, Meyer-Harms et al. 1999). Traditional methods commonly used to study herbivorous zooplankton include using fluorescent (chlorophyll $a$, chl $a$ ) and radioisotope tracers and microscopic cell counting. Chl $a$ and radioisotope tracers provide limited taxonomic information on the ingested phytoplankton, whereas cell counting is time-consuming and small and fragile cells such as microflagellates cannot be counted. The pigment-based technique is less timeconsuming than cell counting and provides better information on the utilization of available phytoplankton resources in comparison to traditional methods, which only measure a bulk parameter such as chl a. Here, we report the results of an investigation of the selective feeding of the mesozooplankton community on different phytoplankton taxa at 2 coastal stations in Hong Kong using HPLC pigment analysis.

The Pearl River is the second largest river in China in terms of annual discharge. Freshwater discharge from the Pearl River carries large amounts of nutrients into the Pearl River estuary in the northern part of the South China Sea and has a significant impact on the hydrography of Hong Kong's coastal waters (Harrison et al. 2008). The flow volume of the Pearl River displays a strong seasonality, reaching a maximum during the wet season from April to September and a minimum during the dry season between October and March (Yin 2003). We chose 2 stations with contrasting hydrography for a comparative investigation of annual cycles (Chen et al. 2009). The western estuarine station (WE, original number NM3, $17 \mathrm{~m}$ depth) is located in the Pearl River estuary representing eutrophic estuarine water, while the eastern oceanic station (EO, original number PM7, $19 \mathrm{~m}$ depth) is located in Port Shelter and influenced mainly by the ocean currents from the South China Sea (see Fig. 1).

\section{MATERIALS AND METHODS}

Sample collection and analysis. Mesozooplankton grazing experiments were carried out monthly from May 2007 to February 2008 at a western estuarine station (WE, $22^{\circ} 21.324^{\prime} \mathrm{N}, 113^{\circ} 56.783^{\prime} \mathrm{E}$ ) and an eastern oceanic station $\left(\mathrm{EO}, 22^{\circ} 20.453^{\prime} \mathrm{N}, 114^{\circ} 17.703^{\prime} \mathrm{E}\right)$ in the coastal areas of Hong Kong (Fig. 1). The water depth is about $17 \mathrm{~m}$ at both sites.

Mesozooplankton was collected by towing a plankton net $(0.5 \mathrm{~m}$ diameter, $167 \mu \mathrm{m}$ mesh size) equipped with a digital flow meter (HYDRO-BIOS) in the upper part of the water column (usually from about $10 \mathrm{~m}$ to surface). Samples were transferred into plastic bottles and adjusted to a volume of $500 \mathrm{ml}$ using $200 \mu \mathrm{m}$ filtered seawater. Duplicate $20 \mathrm{ml}$ subsamples were then filtered onto pre-weighed $20 \mu \mathrm{m}$ polycarbonate (PC) membrane, rinsed with distilled water, and dried in a $60^{\circ} \mathrm{C}$ oven for measurement of mesozooplankton dry weight. The rest of the mesozooplankton samples were preserved in formalin ( $4 \%$ final concentration) for taxonomic identification and counting $(\mathrm{M}$. Chen et al. unpubl. data).

Samples for enumeration of microphytoplankton (mostly diatoms and dinoflagellates) and ciliates were fixed with $5 \%$ acidic Lugol's solution and the cells were counted and sized by the Utermöhl method at $200 \times$ magnification with an Olympus IX51 inverted microscope as described by Chen et al. (2009). Biovolume of diatoms was estimated according to their geometric shapes using the method of Sun \& Liu (2003) and the carbon content was estimated from biovolume based on Eppley et al. (1970).

Mesozooplankton grazing experiments. Live mesozooplankton for grazing experiments were collected by a separate net tow operated in the same way as described above. Live animals were immediately placed into a cooler filled with surface sea water. Ambient sea water for grazing experiments was collected by immersing $20 \mathrm{l}$ polycarbonate carboys below the water surface. The cooler and carboys were then returned to the laboratory and grazing experiments were conducted within $2 \mathrm{~h}$ after the sampling.

Ambient seawater was filtered through a $200 \mu \mathrm{m}$ mesh and siphoned into five $2.4 \mathrm{l} \mathrm{PC}$ bottles. Three PC bottles were then stocked with an aliquot (50 to $100 \mathrm{ml}$ ) of live mesozooplankton and 2 PC bottles were used as controls with no grazers. Duplicates of the same aliquots were collected onto pre-weighed PC membranes to determine the dry weight of the mesozooplankton added to each treatment bottles. Nutrients $\left(10 \mu \mathrm{mol} \mathrm{l} \mathrm{l}^{-1} \mathrm{NaNO}_{3}\right.$ and $\left.1 \mu \mathrm{mol} \mathrm{l} \mathrm{l}^{-1} \mathrm{KH}_{2} \mathrm{PO}_{4}\right)$ were added to all bottles to promote phytoplankton growth. The bottles were then incubated for $24 \mathrm{~h}$ in an outdoor incubator cooled by running seawater. Size- 


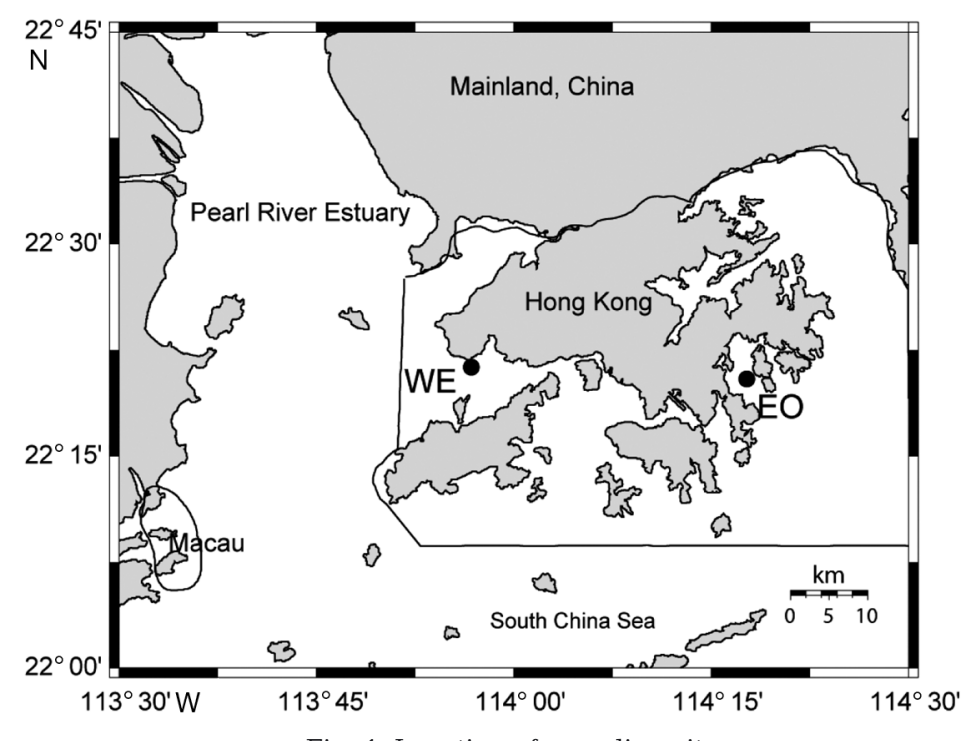

Fig. 1. Location of sampling sites

fractionated chl a concentrations were determined at initial (triplicate) and $24 \mathrm{~h}$ (duplicate from each bottle) time points. Aliquots of 250 to $500 \mathrm{ml}$ were sequentially filtered through 20 and $2 \mu \mathrm{m}$ PC membrane filters and a glass fiber (GF/F) filter under low vacuum pressure. Chlorophylls in the filters were extracted overnight in $90 \%$ acetone at $4^{\circ} \mathrm{C}$ in the dark, and chl a was determined using in vitro fluorescence with a Turner Designs Model 7200 fluorometer (Strickland \& Parsons 1972).

HPLC pigment analysis. For pigment analysis, 500 to $1000 \mathrm{ml}$ subsamples of seawater from grazing and control bottles were filtered through Whatman GF/F filters and stored in a deep-freezer $\left(-80^{\circ} \mathrm{C}\right)$ until analysis. Filters containing phytoplankton were cut into small pieces under dim light. The filter pieces were transferred into centrifuge tubes containing $4 \mathrm{ml} \mathrm{90 \%} \mathrm{ace-}$ tone (HPLC grade, Sigma), which were wrapped with aluminum foil. The contents were sonicated for $5 \mathrm{~min}$ and vortexed. The pigments were extracted overnight at $-20^{\circ} \mathrm{C}$. After extraction, the tubes were centrifuged (4800 rpm) for $20 \mathrm{~min}$ at $4^{\circ} \mathrm{C}$. The supernatants from each tube were collected with disposable $5 \mathrm{ml}$ syringes and passed through Millipore syringe filters (Hydrophobic, PTFE, $0.2 \mu \mathrm{m}$ pore size). Aliquots $(20 \mu \lambda)$ of supernatants were analyzed within $1 \mathrm{~d}$ to minimize pigment losses.

To identify and quantify the phytoplankton pigments, an HPLC (HP Agilent 1100 Series) with an Agilent Eclipse XDB-C18 reversed phase column

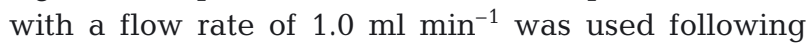
the method of Wong \& Wong (2003). Photosynthetic pigments including $\mathrm{chl} C_{3}$, chl $C_{2}, 19^{\prime}$-butanoyloxyfucoxanthin (But-fuco), peridinin, fucoxanthin, 19'-hexa- noyloxyfucoxanthin (Hex-fuco), diadinoxanthin, alloxanthin, lutein/zeaxanthin (co-eluted), chl $b, \mathrm{chl} a$ and $\beta$-carotene were identified by comparing the retention times with those of commercial authentic pigment standards (International Agency for ${ }^{14} \mathrm{C}$ Determination, Hørsholm, Denmark). The HPLC column was run for $30 \mathrm{~min}$ to ensure that all pigments were retained. Concentrations of each pigment were calculated based on peak areas in the chromatogram and the equation of the standard curve for each pigment.

CHEMTAX analysis. The matrix factorization program CHEMTAX (Mackey et al. 1996) was applied to estimate temporal changes in phytoplankton community structure at the class level at the 2 stations following the method of Latasa (2007). Matrices A to E, artificially generated by Latasa (2007), were used to obtain the most feasible initial pigment:chl a ratios, but Butfuco and haptophytes Type 4 were removed from the calculations in this study because the concentrations of But-fuco, which is present in haptophytes Type 4 (Jeffrey \& Wright 1994), were clearly lower than the other pigments. In addition, since prasinoxanthin was not detected but chl $b$ was often found in this study, the term 'green algae' (i.e. prasinophytes and chlorophytes) is used here. The initial pigment:chl a ratios for green algae in matrices $A$ to $E$ were the same as those of prasinophytes without prasinoxanthin reported by Latasa (2007). Monthly pigment data at the 2 stations were treated separately for the CHEMTAX analyses. Ten successive runs of CHEMTAX among matrices A to $\mathrm{E}$ were made. The convergence of different pigment ratios with the successive runs is directed towards the true values (Latasa 2007). Therefore, we averaged the final pigment ratios from those that were convergent after the 10 successive runs among the 5 matrices to obtain the most promising initial pigment ratios before incubation at each station.

For estimates of phytoplankton community composition after incubation, the averaged final pigment ratios obtained using the above-mentioned procedures with the monthly pigment data were entered into the seed matrix. We confirmed that the final pigment matrices showed little change even after several further CHEMTAX runs using the monthly pigment data. Therefore, the final pigment matrices mentioned above were simply used as the initial pigment matrices for estimating the selective grazing of mesozooplankton after incubation.

Rate calculation. Changes in total chl a or in the abundance of each taxonomic group after grazing were used to calculate the mesozooplankton clearance $(F)$ and ingestion $(I)$ rates using the equations of Frost (1972):

$$
F\left(1 \cdot \mathrm{mg}^{-1} \cdot \mathrm{d}^{-1}\right)=\frac{k_{c}-k_{t}}{d w}
$$




$$
I\left(\mu \mathrm{g} \mathrm{chl} \cdot \mathrm{mg}^{-1} \cdot \mathrm{d}^{-1}\right)=F \times \bar{C}
$$

where $k_{c}$ and $k_{\mathrm{t}}$ are the growth rates of total or specific phytoplankton taxa in controls and treatments, respectively, calculated from the equation:

$$
k=\left(\ln \frac{C_{e}}{C_{0}}\right) / t
$$

where $C_{0}$ and $C_{\mathrm{e}}$ are the taxon-specific chl a concentrations at the beginning and the end of the grazing, respectively. $d w\left(\mathrm{mg} \cdot \mathrm{l}^{-1}\right)$ is the dry weight of mesozooplankton that was added to the treatment bottles, and
$\bar{C}$ is the mean concentration of chl a during grazing incubation, which can be calculated by the equation $\bar{C}=\left(C_{\mathrm{e}}-C_{0}\right) / \mathrm{k} / t_{\text {, where }} t(\mathrm{~d})$ is the time of incubation.

The mesozooplankton feeding selectivity index $\left(\alpha_{i}\right)$ was calculated by comparing the frequency distribution of specific prey in the environment and in the diet (Chesson 1978). This index varies between 0 and 1. When $\alpha_{i}=m^{-1}$, where $m$ is the number of prey types, feeding is unselective. In this study $m=6$ and $\alpha_{i}=6^{-1} \approx$ 0.17 . An $\alpha_{i}>0.17$ indicates a feeding preference by mesozooplankton, whereas an $\alpha_{i}<0.17$ indicates avoidance.

Table 1. CHEMTAX analysis of accessory pigment to chl a ratios in the major algal groups at stations EO and WE. Chl c3: chlorophyll $c 3$; per: peridinin; fuco: fucoxanthin; 19hex: 19'-hexanoyloxyfucoxanthin; allo: alloxanthin; zea: zeaxanthin; chl $b$ : chloro-

\begin{tabular}{|c|c|c|c|c|c|c|c|c|}
\hline & Chl $c 3$ & Per & Fuco & 19hex & Allo & Zea & Chl $b$ & $\mathrm{Chl}$ c \\
\hline \multicolumn{9}{|l|}{ EO } \\
\hline \multicolumn{9}{|l|}{ Initial ratios } \\
\hline Green algae & 0 & 0 & 0 & 0 & 0 & 0.01 & 0.158 & 1 \\
\hline Dinoflagellates & 0 & 1.183 & 0 & 0 & 0 & 0 & 0 & 1 \\
\hline Cryptophytes & 0 & 0 & 0 & 0 & 0.147 & 0 & 0 & 1 \\
\hline Haptophytes-3 & 0.046 & 0 & 0 & 0.783 & 0 & 0 & 0 & 1 \\
\hline Synechococcus & 0 & 0 & 0 & 0 & 0 & 0.775 & 0 & 1 \\
\hline Diatoms & 0 & 0 & 0.717 & 0 & 0 & 0 & 0 & 1 \\
\hline \multicolumn{9}{|c|}{ Final ratios for samples before incubation } \\
\hline Green algae & 0 & 0 & 0 & 0 & 0 & 0.039 & 0.623 & 1 \\
\hline Dinoflagellates & 0 & 1.183 & 0 & 0 & 0 & 0 & 0 & 1 \\
\hline Cryptophytes & 0 & 0 & 0 & 0 & 0.147 & 0 & 0 & 1 \\
\hline Haptophytes-3 & 0.046 & 0 & 0 & 0.783 & 0 & 0 & 0 & 1 \\
\hline Synechococcus & 0 & 0 & 0 & 0 & 0 & 0.775 & 0 & 1 \\
\hline Diatoms & 0 & 0 & 0.959 & 0 & 0 & 0 & 0 & 1 \\
\hline \multicolumn{9}{|c|}{ Final ratios for samples after incubation } \\
\hline Green algae & 0 & 0 & 0 & 0 & 0 & 0.039 & 0.623 & 1 \\
\hline Dinoflagellates & 0 & 1.183 & 0 & 0 & 0 & 0 & 0 & 1 \\
\hline Cryptophytes & 0 & 0 & 0 & 0 & 0.147 & 0 & 0 & 1 \\
\hline Haptophytes-3 & 0.046 & 0 & 0 & 0.783 & 0 & 0 & 0 & 1 \\
\hline Synechococcus & 0 & 0 & 0 & 0 & 0 & 0.957 & 0 & 1 \\
\hline Diatoms & 0 & 0 & 0.959 & 0 & 0 & 0 & 0 & 1 \\
\hline \multicolumn{9}{|l|}{ WE } \\
\hline \multicolumn{9}{|l|}{ Initial ratios } \\
\hline Green algae & 0 & 0 & 0 & 0 & 0 & 0.010 & 0.794 & 1 \\
\hline Dinoflagellates & 0 & 1.266 & 0 & 0 & 0 & 0 & 0 & 1 \\
\hline Cryptophytes & 0 & 0 & 0 & 0 & 0.187 & 0 & 0 & 1 \\
\hline Haptophytes-3 & 0.061 & 0 & 0 & 0.539 & 0 & 0 & 0 & 1 \\
\hline Synechococcus & 0 & 0 & 0 & 0 & 0 & 0.726 & 0 & 1 \\
\hline Diatoms & 0 & 0 & 0.872 & 0 & 0 & 0 & 0 & 1 \\
\hline \multicolumn{9}{|c|}{ Final ratios for samples before incubation } \\
\hline Green algae & 0 & 0 & 0 & 0 & 0 & 0.010 & 0.794 & 1 \\
\hline Dinoflagellates & 0 & 1.266 & 0 & 0 & 0 & 0 & 0 & 1 \\
\hline Cryptophytes & 0 & 0 & 0 & 0 & 0.187 & 0 & 0 & 1 \\
\hline Haptophytes-3 & 0.073 & 0 & 0 & 0.539 & 0 & 0 & 0 & 1 \\
\hline Synechococcus & 0 & 0 & 0 & 0 & 0 & 0.726 & 0 & 1 \\
\hline Diatoms & 0 & 0 & 0.872 & 0 & 0 & 0 & 0 & 1 \\
\hline \multicolumn{9}{|c|}{ Final ratios for samples after incubation } \\
\hline Green algae & 0 & 0 & 0 & 0 & 0 & 0.01 & 0.794 & 1 \\
\hline Dinoflagellates & 0 & 1.266 & 0 & 0 & 0 & 0 & 0 & 1 \\
\hline Cryptophytes & 0 & 0 & 0 & 0 & 0.187 & 0 & 0 & 1 \\
\hline Haptophytes-3 & 0.073 & 0 & 0 & 0.539 & 0 & 0 & 0 & 1 \\
\hline Synechococcus & 0 & 0 & 0 & 0 & 0 & 0.726 & 0 & 1 \\
\hline Diatoms & 0 & 0 & 1.302 & 0 & 0 & 0 & 0 & 1 \\
\hline
\end{tabular}
phyll $b$; chl $a$ : chlorophyll $a$ 


\section{RESULTS}

\section{CHEMTAX analysis}

The matrices of initial values and the final ratios of accessory pigments to chl $a$ in the major algal groups for CHEMTAX analyses, generated according to the procedures of Latasa (2007), are given in Table 1. We have generated separate matrices for samples before and after incubation at each study site (a total of 4 sets of final ratios). The final pigment/chl a ratios obtained were within the range of published values (Mackey et al. 1996). Significant correlation occurred between diatom-derived chl a estimated by CHEMTAX and carbon biomass of diatoms estimated by microscopy (Fig. 2$)$ at $E O\left(r^{2}=0.405, p<0.05\right)$, but not at WE. When the 2 outliers (August and October) were excluded, the correlation at WE was significant $\left(\mathrm{r}^{2}=0.764, \mathrm{p}=0.002\right)$.

\section{Seasonal variation of phytoplankton compositions}

Phytoplankton community compositions in terms of absolute biomass and relative contributions to total $\mathrm{chl} a$ at the 2 sampling sites are shown in Fig. 3. Phytoplankton at EO was dominated by diatoms except in August. Chl a derived from diatoms ranged from 0.027 to $0.64 \mathrm{\mu g} \mathrm{l}^{-1}$, corresponding to $8.6-65.8 \%$ of the total chl a. Although the mean chl a concentrations of diatoms did not differ significantly between the mixing period (September to February) and stratification period (April to August), diatoms accounted for a much higher percentage of total chl a during the mixing period than the stratification period (1-way ANOVA; $\mathrm{p}=0.027)$. Cryptophytes, the second most dominant

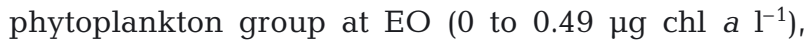
accounted for 0 to $40.4 \%$ of total chl a. Like diatoms, the mean percentage of chl a contributed by cryptophytes was also significantly higher in the mixing period (from October to February) than in the stratification months (from April to July) (1-way ANOVA; $\mathrm{p}=$ 0.008). Cryptophyte biomass was near zero in August and September (Fig. 3A,B). Green algae and cyanobacteria (mainly Synechococcus, see Discussion), which are the main component of ultra-phytoplankton, constituted an average of 13.5 and $11.1 \%$ of total chl $a_{\text {, }}$ respectively. The contribution of Synechococcus to the chl a biomass was higher during the stratification period than during the mixing period (1-way ANOVA, $\mathrm{p}<0.05)$. The contribution of green algae lacked a clear seasonal pattern $(p>0.05)$, but showed a peak in June and was extremely low in July and January. The relative contribution of the small flagellates group, haptophytes Type 3, remained low throughout the year, averaging at approximately 10\%. Autotrophic

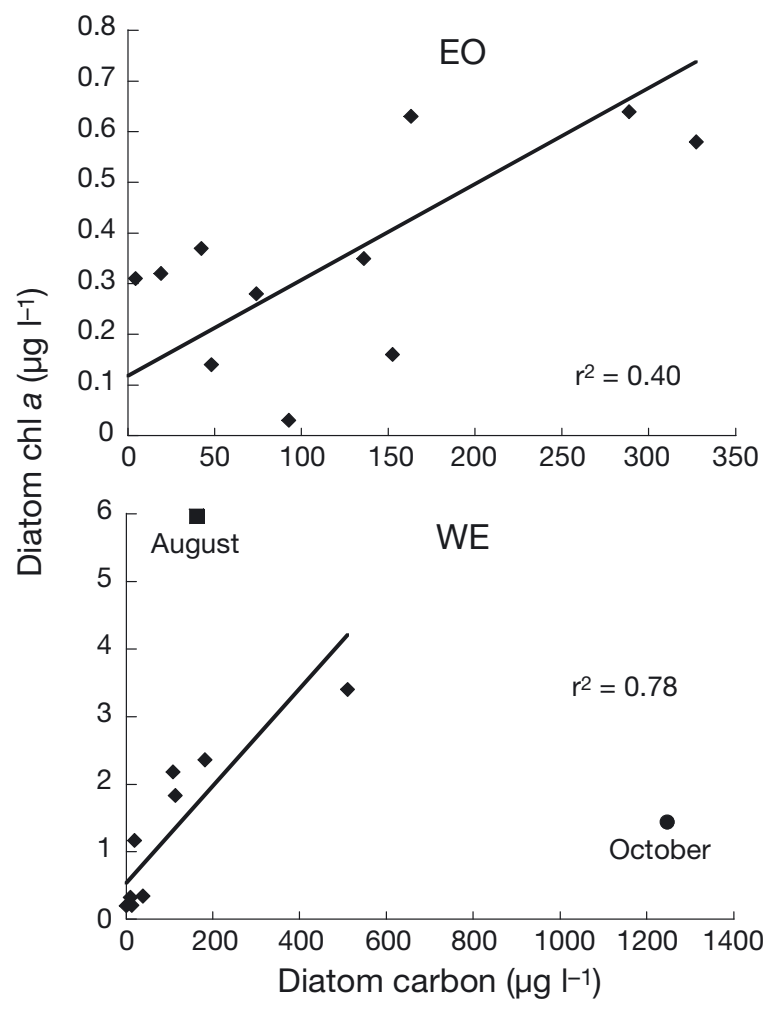

Fig. 2. Correlation between diatom chl a estimated from HPLC pigment analysis and the CHEMTAX program, and diatom biomass calculated from microscopic observations for samples from coastal (EO) and estuarine (WE) waters. Lines fitted to the data are Model II regressions. (ם), (•) outliers

dinoflagellates, the least important contributor to total chl $a$, averaged approximately $7.5 \%$ and reached a peak of $22.1 \%$ in August when dinoflagellates were the most dominant group.

Diatoms and cryptophytes were also the 2 most dominant groups of phytoplankton at WE (Fig. 3C,D). Diatom-derived chl a ranged from 0.213 to $5.973 \mu \mathrm{g} \mathrm{l}^{-1}$, accounting for 16.8 to $67.5 \%$ of total chl a. Diatom concentrations were extremely low in June when the freshwater discharge from Pearl River reached a peak. Excluding June, both the mean biomass and relative contribution of diatoms were significantly higher during the wet season (from April to September) than during the dry season (from October to February) (1-way ANOVA $_{i} \mathrm{p}<0.05$ and $\mathrm{p}<0.01$, respectively). Chl a concentrations and the relative percentage of cryptophytes ranged from 0.202 to $2.423 \mathrm{\mu g} \mathrm{l}^{-1}$ and 10 to $55.2 \%$, respectively, and showed no clear seasonal pattern. The other 4 groups of phytoplankton were never dominant at WE. The only exception was dinoflagellates, which constituted $35.5 \%$ of the total chl a in November. Green algae and Synechococcus constituted, on average, only $6.8 \%$ and $3.4 \%$ of the total $\mathrm{chl} a_{1}$ respectively. Both groups were relatively 


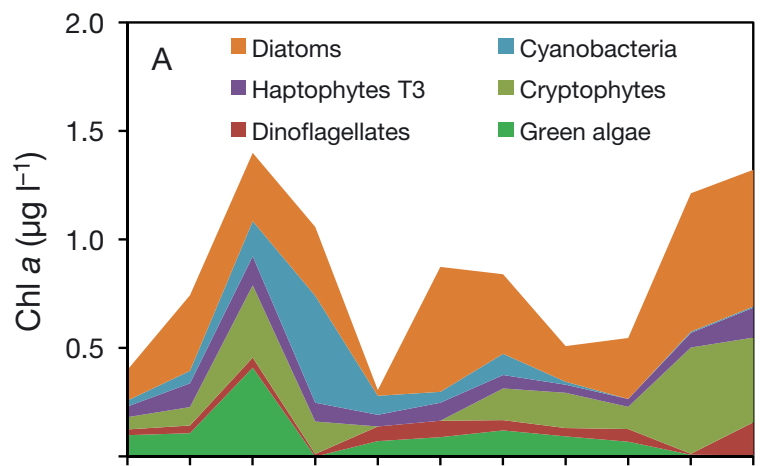

Apr May Jun Jul Aug Sep Oct Nov Dec Jan Feb
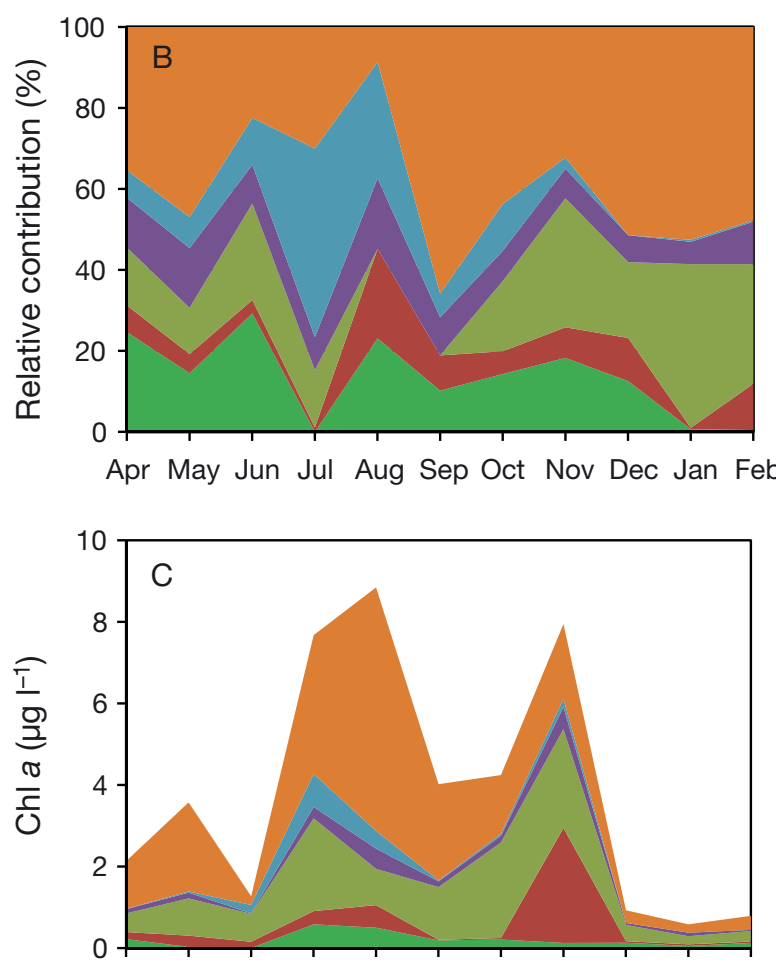

Apr May Jun Jul Aug Sep Oct Nov Dec Jan Feb

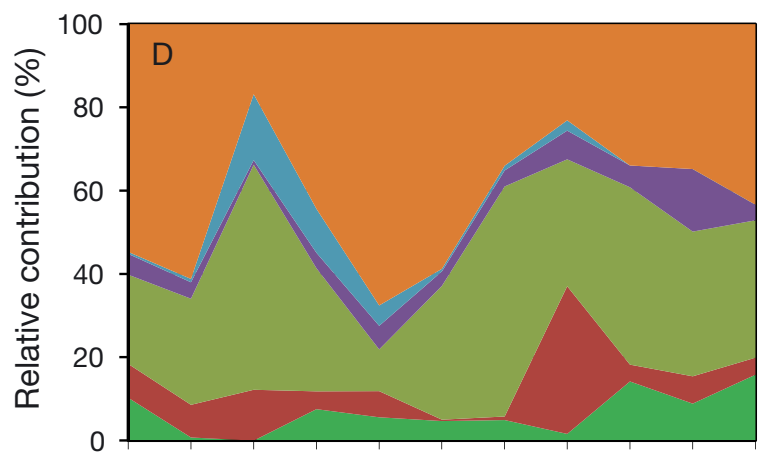

Apr May Jun Jul Aug Sep Oct Nov Dec Jan Feb

Fig. 3. Seasonal variations in chl a concentrations from different phytoplankton groups and the relative contribution of different phytoplankton groups to total chl $a$ at $(\mathrm{A}, \mathrm{B})$ the EO site and $(C, D)$ the WE site more abundant in summer. Haptophytes accounted for $5.2 \%$ of total chl a with little variability throughout the year.

Comparing the 2 sites, the diatom-derived chl a concentration was significantly higher at WE than at EO (paired $t$-test, $\mathrm{p}<0.05, \mathrm{df}=10$ ), but its contribution to total chl a did not differ significantly between the 2 sites (independent $t$-test, $\mathrm{p}>0.05$ ). On the other hand, both the concentration and relative contribution of cryptophytes were significantly higher at WE than at EO (paired $t$-test, $\mathrm{p}=0.006$ ). However, no statistically significant difference in the percentage monthly contribution to total chl a biomass by each phytoplankton group was found between the 2 sites $\left(\chi^{2}\right.$ test of independence, $\mathrm{p}=0.224$ ).

Generally, the chl a concentrations from diatoms increased linearly with total chl a concentrations from microphytoplankton (i.e. chl $a$ in $>20 \mu$ m fraction) measured by the fluorometric method. Similarly, chl a concentrations from cryptophytes increased linearly with total chl a concentrations associated with nanophytoplankton (i.e. chl $a$ in the 2 to $20 \mu \mathrm{m}$ fraction) (Fig. 4).
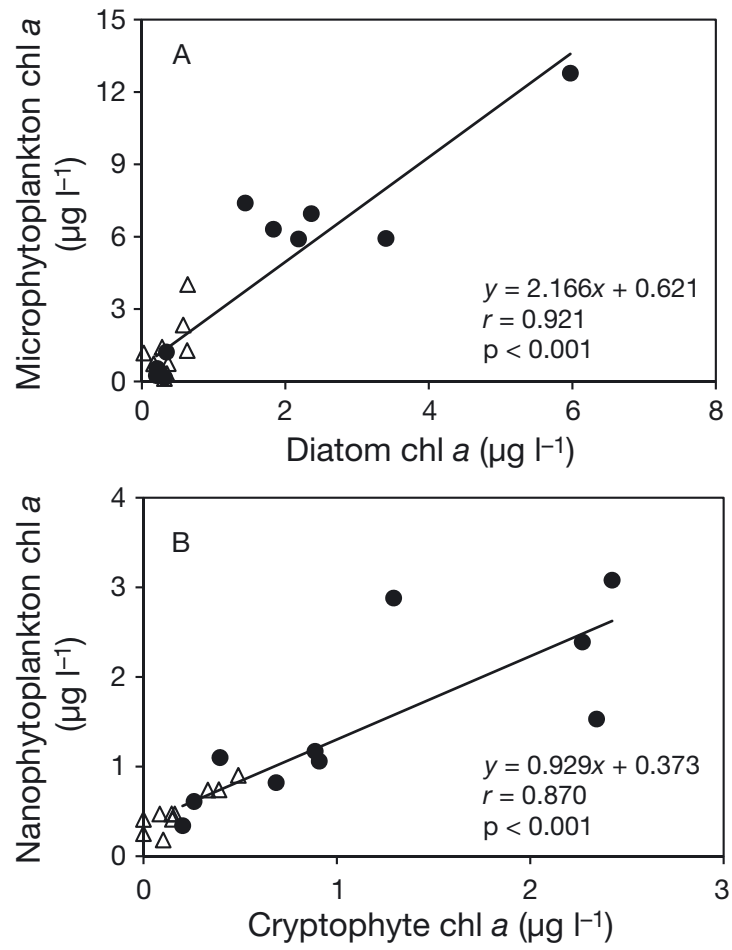

Fig. 4. Relationship between chl a concentrations in (A) microphytoplankton $(>20 \mu \mathrm{m})$ and diatoms; and (B) in nanophytoplankton (2 to $20 \mu \mathrm{m}$ ) and cryptophytes. Chl a concentrations in micro- and nanophytoplankton were measured by fluorometer and were estimated by CHEMTAX analysis of HPLC measured pigments in diatoms and cryptophytes. $\triangle \mathrm{EO}$ and $\bullet \mathrm{WE}$ 

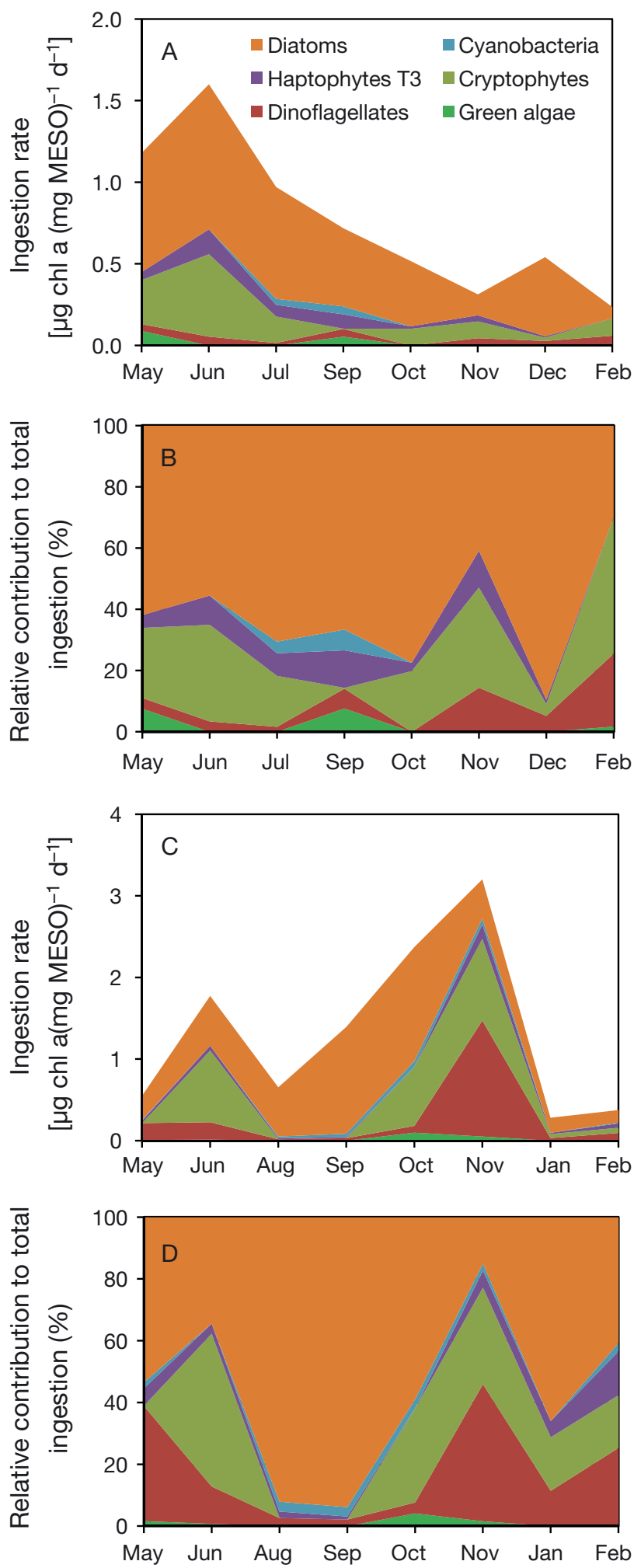

Fig. 5. Seasonal variations in mesozooplankton ingestion rates of different phytoplankton groups and the relative contribution of different phytoplankton groups to total ingestion by mesozooplankton. (A) Ingestion rates at $\mathrm{EO}_{\text {; }}$ (B) relative contribution at $\mathrm{EO}_{;}(\mathrm{C})$ ingestion rates at $\mathrm{WE}$; (D) relative contribution at WE

\section{Mesozooplankton ingestion of specific phytoplankton groups}

The seasonal variations in mesozooplankton ingestion of different phytoplankton taxa and the relative contribution of different phytoplankton taxa to the mesozooplankton diet are presented in Fig. 5. At EO, diatoms and cryptophytes comprised about $80 \%$ of the phytoplankton ingested by mesozooplankton. Only a small fraction of the total ingestion consisted of haptophytes and dinoflagellates (averaged $<10 \%$ ). Dinoflagellates were a relatively important prey item during late autumn and winter, accounting for $23.8 \%$ of the total ingestion. Synechococcus and green algae were not important food for mesozooplankton.

Diatoms and cryptophytes, the main food of mesozooplankton at WE, comprised around $75 \%$ of the total ingestion. However, unlike the situation at EO, dinoflagellates also formed an important food item of mesozooplankton at WE, except in the late- and poststratification period between August and October when diatoms comprised up to $90 \%$ of the total ingestion. Similar to EO, $<5 \%$ of the total ingestion consisted of haptophytes, green algae and Synechococcus.

\section{Mesozooplankton feeding selectivity}

The mean clearance rates of different phytoplankton components by mesozooplankton (Fig. 6) are indica-

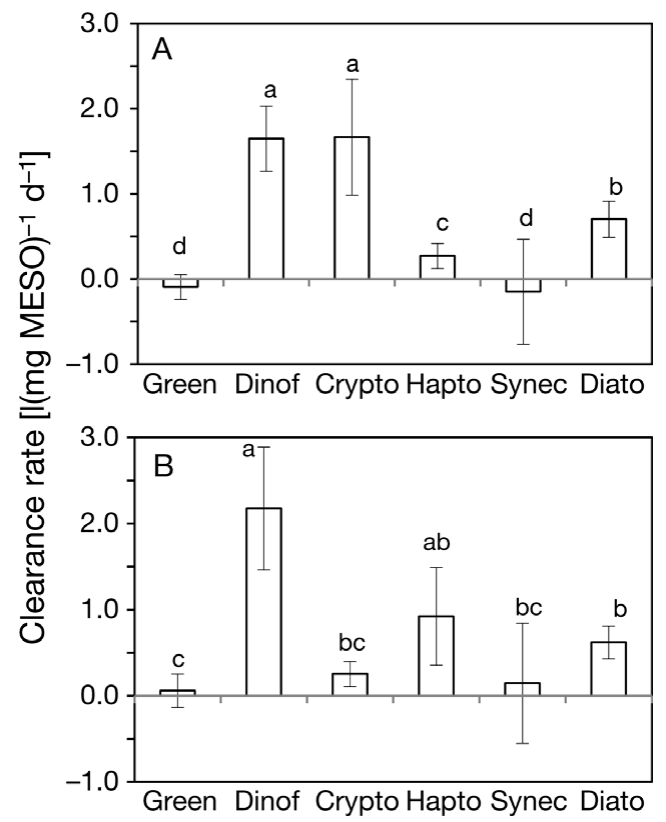

Fig. 6. Clearance rates (mean $\pm \mathrm{SE}$ ) of mesozooplankton on different phytoplankton groups at (A) EO and (B) WE. Clearance rates that differ significantly from each other (1-way ANOVA with $\mathrm{p}<0.05$ ) are indicated by different letters 
tive of the prey preference or selective feeding of mesozooplankton. At EO, the mean clearance rates of dinoflagellates and cryptophytes by mesozooplankton were significantly higher than those of other phytoplankton taxa (independent $t$-test, $\mathrm{p}<0.05, \mathrm{n}=16$ ). Clearance rates of green algae and Synechococcus were negative, suggesting a cascading effect induced by mesozooplankton (see Discussion). At WE, mean clearance rates were high for dinoflagellates but low for cryptophytes. Relatively high clearance rates were also found for diatoms and haptophytes, while mean clearance rates of green algae and cyanobacteria were close to zero.

The selectivity index $\alpha_{\mathrm{i}}$ was used to test the degrees of mesozooplankton selectivity for specific phytoplankton groups (Fig. 7). Table 2 summarizes the sig- nificance levels of differences in $\alpha_{\mathrm{i}}$-values between specific phytoplankton groups. At EO, the $\alpha_{\mathrm{i}}$-values for dinoflagellates and cryptophytes were consistently higher than the threshold $\left(\alpha_{i}=0.17\right)$ for selective feeding, showing that mesozooplankton had a positive preference for these 2 phytoplankton groups, especially dinoflagellates. The average $\alpha_{\mathrm{i}}$-value for diatoms was around the threshold, indicating that mesozooplankton generally had no feeding selection for diatoms. Avoidance of diatoms by mesozooplankton occurred in September, November and February when the $\alpha_{\mathrm{i}}$-values of diatoms were extremely low. The $\alpha_{\mathrm{i}}$ values for haptophytes, green algae and Synechococcus were significantly lower than those for the other 3 phytoplankton groups, and were much lower than the selection threshold in most cases. These results indi-

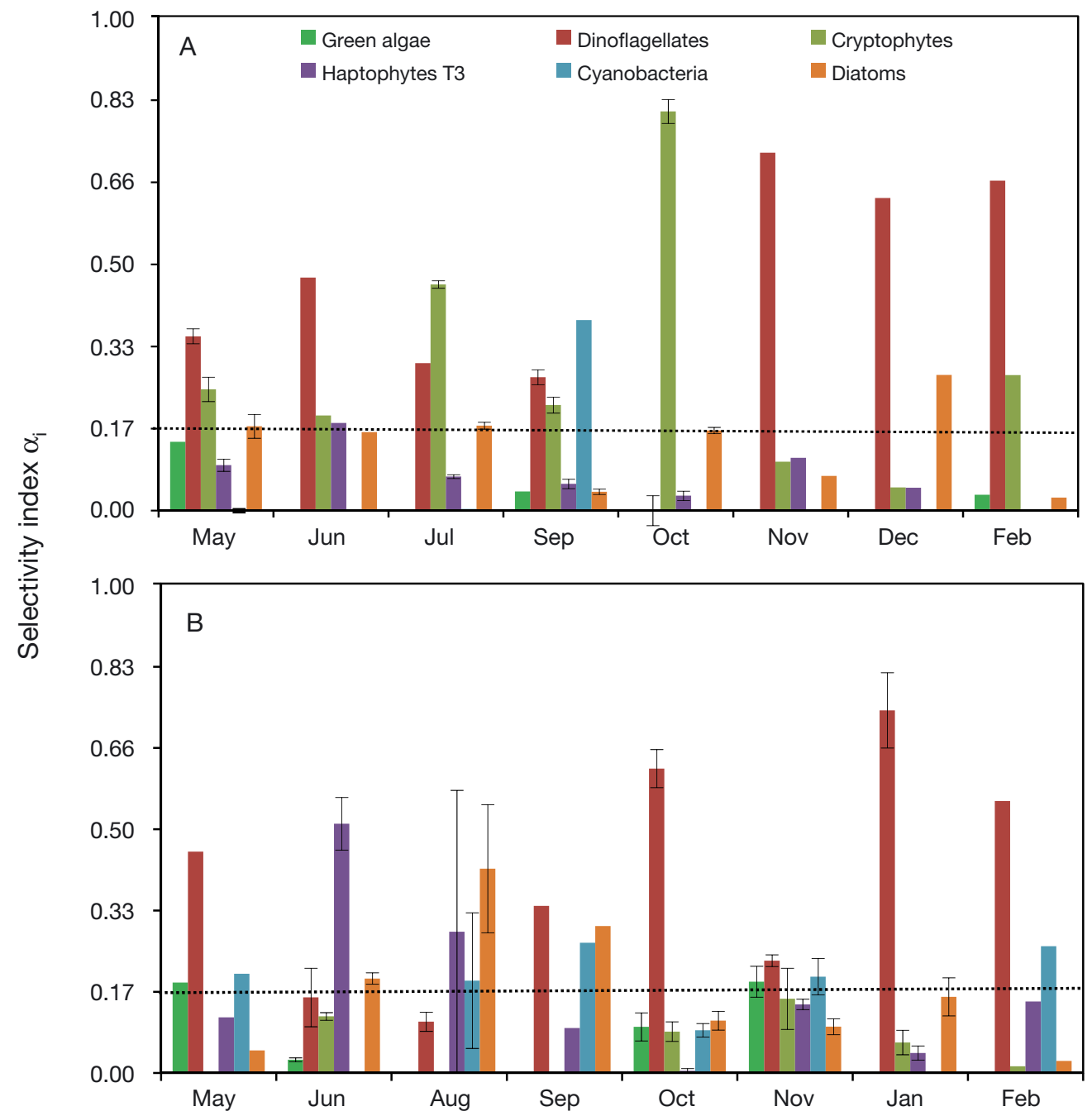

Fig. 7. Seasonal variations in mesozooplankton feeding selectivity index $\left(\alpha_{i}\right)$ for different phytoplankton groups at (A) EO and (B) WE. The dotted line shows the $\alpha_{\mathrm{i}}$-value $(0.17)$ that represents no selectivity. Values above the line indicate preference and values below the line mean avoidance. Error bar indicates SE among replicates 
Table 2. Significance levels ( $p$ values) of differences in $\alpha_{\mathrm{i}}$-values between specific phytoplankton groups using the 2-sample Kolmogorov-Smirnov test (non-parametric test of difference between 2 independent samples). Bold: significant difference

\begin{tabular}{|lrrrrr|}
\hline & $\begin{array}{c}\text { Green } \\
\text { algae }\end{array}$ & $\begin{array}{c}\text { Dino- } \\
\text { flagellates }\end{array}$ & $\begin{array}{c}\text { Crypto- } \\
\text { phytes }\end{array}$ & Hapto- Synecho- \\
phytes & coccus \\
\hline EO & & & & & \\
Green algae & & & & & \\
Dinoflagellates & $<\mathbf{0 . 0 0 1}$ & & & & \\
Cryptophytes & $<\mathbf{0 . 0 0 1}$ & 0.069 & & & \\
Haptophytes & $\mathbf{0 . 0 0 1}$ & $<\mathbf{0 . 0 0 1}$ & $\mathbf{0 . 0 0 3}$ & & \\
Synechococcus & 0.794 & $<\mathbf{0 . 0 0 1}$ & $\mathbf{< . 0 0 1}$ & $<\mathbf{0 . 0 0 1}$ & \\
Diatoms & $<\mathbf{0 . 0 0 1}$ & $<\mathbf{0 . 0 0 1}$ & 0.152 & $\mathbf{0 . 0 0 3}$ & $<\mathbf{0 . 0 0 1}$ \\
WE & & & & & \\
Green algae & & & & & \\
Dinoflagellates & $\mathbf{0 . 0 0 4}$ & & & & \\
Cryptophytes & 0.669 & $<\mathbf{0 . 0 0 1}$ & & & \\
Haptophytes & 0.211 & $\mathbf{0 . 0 1 3}$ & 0.211 & & \\
Synechococcus & 0.669 & $\mathbf{0 . 0 3 7}$ & 0.415 & 0.669 & \\
Diatoms & $\mathbf{0 . 0 1 3}$ & $\mathbf{0 . 0 3 7}$ & $\mathbf{0 . 0 3 7}$ & 0.669 & 0.211 \\
& & & & & \\
\hline
\end{tabular}

cate that mesozooplankton did not feed effectively on these 3 kinds of preys. Surprisingly, a positive feeding selectivity for Synechococcus was observed in September (Fig. 7).

Mesozooplankton also exhibited a preference for dinoflagellates at WE. However, the low $\alpha_{\mathrm{i}}$-values for dinoflagellates during summer indicate a decline in selectivity toward dinoflagellates at this time. The $\alpha_{i-}$ values for dinoflagellates did not differ between the 2 sites (1-way ANOVA, $\mathrm{p}=0.73, \mathrm{n}=16$ ). The $\alpha_{\mathrm{i}}$-values for diatoms also did not differ between the 2 sites (1-way ANOVA, $p=0.61, n=16$ ). In fact, the $\alpha_{i}$-values for diatoms were below the selective threshold in half of the experiments. However, high $\alpha_{\mathrm{i}}$-values for diatoms occurred during diatom blooms in August and September. Unlike EO (1-way ANOVA; $\mathrm{p}=0.002, \mathrm{n}=$ $16)$, the $\alpha_{i}$-values for cryptophytes were very low at WE, indicating that the mesozooplankton at this site did not like to feed on cryptophytes. Also different from EO was that the $\alpha_{\mathrm{i}}$-values for haptophytes (1-way ANOVA; $\mathrm{p}=0.034, \mathrm{n}=16$ ) and Synechococcus (1-way ANOVA; $\mathrm{p}=0.01, \mathrm{n}=16$ ) were both around 0.17 , indicating no selection for or against these 2 prey by the mesozooplankton assemblages. Similar to EO (1-way ANOVA; $\mathrm{p}=0.13, \mathrm{n}=16$ ), mesozooplankton avoided green algae in most instances.

\section{DISCUSSION}

The combination of grazing incubation experiments and HPLC pigment analysis provided a fruitful approach through which detailed diet compositions of mesozooplankton could be revealed (see also Verity \& Paffenhöfer 1996). This information is important as it can provide necessary insights into: (1) factors that affect the population dynamics of mesozooplankton, which are a critical link between primary production and fisheries, and (2) how mesozooplankton may contribute to shaping the phytoplankton community structure as well as the overall microbial food web.

To achieve these goals by accurately converting pigment concentrations into real phytoplankton biomasses, we carefully divided the samples from each site into those taken directly from the monthly survey and those incubated in grazing experiments and calculated the pigment to chl a ratios separately (i.e. a total of 4 matrices shown in Table 1). This allowed us to minimize interference from field light and nutrient conditions, species composition, and phytoplankton physiological conditions. Successful estimates of phytoplankton community structure from pigment data using the CHEMTAX program rely largely on the initial choice of pigment to chl a ratios, which can vary with species (e.g. Jeffrey \& Wright 1994, Irigoien et al. 2004), irradiance and nutrients (e.g. Goericke \& Montoya 1998, Henriksen et al. 2002, Rodríguez et al. 2006). Reasonably good correlation between diatom-derived chl a levels and the microscopic estimates of diatom-derived carbon was found at the coastal site, validating the CHEMTAX outputs. Good correlation was also obtained at the estuarine site if 2 outliers (August and October) were excluded (Fig. 2). The dominant species in August were Skeletonema costatum, Pseudo-nitzschia delicatissima and $S$. tropicum, whereas those in October were S. costatum and Chaetoceros curvisetus, which had the highest diatom abundance during the study period (Chen et al. 2009). Previously, better agreement between the 2 techniques was found for large diatoms than for small flagellates (Rodríguez et al. 2002, Garribotti et al. 2003, Llewellyn et al. 2005). The discrepancy between the 2 approaches was probably caused by ambiguity of some chemotaxonomic pigments (Irigoien et al. 2004), uncertain bio-volume to carbon conversion factors (Montagnes et al. 1994), or simply the large variation in carbon-to-chlorophyll ratios among different dominant species and different growth stages.

One possible issue that may cause bias and inaccurate estimation of taxon-specific mesozooplankton grazing rates in our approach is the inclusion of fecal materials that contain partially digested pigment in the samples. While recognizing that pigment degradation and alteration are likely to occur in the gut of herbivorous zooplankton and different marker pigments may be degraded to a different extent in the fecal pellets 
(e.g. Nelson 1989), we were not able to address this potential problem in a quantitative way in this study.

Diatoms were the most abundant phytoplankton group and potentially the most important food for mesozooplankton throughout the year (Figs. 3 \& 5), but showed a great deal of variation in the feeding selectivity index of mesozooplankton (Fig. 7). Our finding is consistent with the general view that diatoms are often considered the most abundant food for copepods (Cushing 1989). However, some recent studies have suggested detrimental effects of diatoms on copepod reproduction, probably due to toxic aldehydes (e.g. Miralto et al. 1999), but other studies have shown no negative effect of a diatom-dominated diet (e.g. Irigoien et al. 2002). Indeed, we recorded more avoidance of than preference for diatoms by mesozooplankton in our experiments (Fig. 7), and these results did not appear to be closely related to any specific diatom species. For example, Skeletonema costatum, together with Pseudo-nitzschia delicatissima, was the most dominant diatom species at WE in August and September (Chen et al. 2009) when diatoms were the favorite food of mesozooplankton (Fig. 7), and it was also the most dominant species in some of the months when diatoms were negatively discriminated by mesozooplankton. Without firm evidence, we speculate that the nutritional value of the diatoms, which may be higher during early stages of blooms, may have led to the increased ingestion in August and September.

One salient finding of our study is that mesozooplankton assemblages in both subtropical estuarine and coastal waters strongly prefer peridinin-containing dinoflagellates over other types of phytoplankton. Some dinoflagellates are non-pigmented or may possess fucoxanthin or Hex-fuco instead of peridinin (Wright \& Jeffrey 2006), but these taxa could not be assessed in this study. Selection of dinoflagellates over diatoms in our study did not appear to be related to size as there is no significant difference between the sizes of the 2 types of phytoplankton (data not shown). Meyer-Harms et al. (1999) reported that Calanus finmarchicus in the Norwegian Sea selected dinoflagellates over diatoms, even though dinoflagellates were of minor importance in the natural population (the same as our study) and were smaller than diatoms. There have been conflicting reports on the nutritional quality of dinoflagellates. In general, they are considered to be an important food of copepods because of their higher volume-specific organic content then diatoms (Hitchcock 1982, Kleppel 1993). It has been demonstrated that copepods on a dinoflagellate diet increase their egg production and survival rates because most dinoflagellates contain high amounts of essential fatty acids, such as DHA (Shin et al. 2003, Sushchik et al. 2004). On the other hand, some dinofla- gellate species, such as Karenia brevis (Prince et al. 2006) and Prorocentrum minimum (Dam \& Colin 2005), are considered to be nutritionally insufficient poor food for copepods. Nonetheless, it is almost certain that any monodiet of diatoms or dinoflagellates is nutritionally inadequate to the growth and reproduction of copepods (Jones \& Flynn 2005). However, when both diatoms and dinoflagellates are available, preferential selective grazing on the dinoflagellates over diatoms have been observed in both laboratory (Jones \& Flynn 2005) and field (Atkinson 1996, Meyer-Harms et al. 1999, Liu et al. 2005b) studies. Our findings appear to conform to the optimal foraging theory (DeMott 1989), which predicts that in sites where food is abundant, mesozooplankton tend to exhibit a preference for high quality food such as dinoflagellates. In fact, copepods have been reported to even feed selectively on toxic dinoflagellates, such as Alexandrium lusitanicum (Dutz 1998) and A. minutum (Barreiro et al. 2006), and to use toxin-dilution mechanisms to reduce the toxic effects (Barreiro et al. 2006). Thus, dinoflagellates probably contribute disproportionally to the upper trophic level production in productive coastal waters.

Evidence arising from our experiments suggests that mesozooplankton composition could partially explain the spatial and temporal variations in grazing selectivity and, therefore, probably impose a driving force for shaping phytoplankton community structure (Leibold et al. 1997). Positive selectivity on Synechococcus (and negative selectivity on diatoms as discussed in the previous paragraph) in September in the eastern waters was likely related to the high abundance of mollusca larvae (about $9200 \mathrm{~m}^{-3}$, or $22.2 \%$ of total mesozooplankton) and the marine cladoceran Evadne tergestina $\left(9000 \mathrm{~m}^{-3}\right.$, or $21.7 \%$ of total mesozooplankton, M. Chen et al. unpubl. data). Similarly, in the western estuarine waters, mesozooplankton selectively feeding on haptophytes coincided with periods of high abundance of copepod nauplii (75\% of total mesozooplankton). Likewise, Sommer et al. (2000) found that in Kiel Bight, Germany, bivalve veligers and appendicularians are responsible for the removal of particles $<2 \mu \mathrm{m}$ in size, while seston size fractions larger than $5 \mu \mathrm{m}$ were mainly cleared by copepods and nauplii. We must emphasize that, most of the time, the mesozooplankton assemblages at the 2 study sites were dominated by small copepods, such as Parvocalanus crassirostris, Oithona brevicornis, O. simplex, Acartia spinicauda, Paracalanus aculeatus and $P$. parvus (M. Chen et al. unpubl.). Consequently, low or negative clearances of green algae and cyanobacteria (presumably Synechococcus), both of which are major components of picophytoplankton at the study sites (Chen et al. 2009, H. Jing et al. 2010), were consistently observed. Such results agree with previous studies 
(Meyer-Harms \& von Bodungen 1997, Meyer-Harms et al. 1999) which reported that cyanobacteria and green algae are avoided by calanoid copepods.

Marine mesozooplankton are often dominated by copepods that capture large-sized prey, including heterotrophic protists, most efficiently. Since micro- and nano-sized protists are the major consumers of picophytoplankton (Calbet \& Landry 2004, Chen et al. 2009), a trophic cascade induced by mesozooplankton predation on protozoa often occurs in marine ecosystems (Landry et al. 1993; Calbet \& Landry 1999; Liu \& Dagg, 2003; Liu et al. 2005a). As green algae and picocyanobacteria are among the major components of picophytoplankton (Liu et al. 1998, Moon-van der Staay et al. 2001, Suzuki et al. 2002a, Not et al. 2004, H. Jing et al. 2010), it is likely that the negative clearance rates of these 2 algal groups by mesozooplankton could partially be the result of a trophic cascade induced by mesozooplankton predation on phagotrophic protists. Of course, microzooplankton grazing occurred on all phytoplankton taxa in both control and treatment bottles (Latasa et al. 1997), the positive mesozooplankton clearance rates on other algal groups simply means that the mortality of these algal groups from mesozooplankton direct feeding surpassed the population increase due to the release of microzooplankton grazing pressure caused by the trophic cascade.

Overall, mesozooplankton assemblages in subtropical eutrophic coastal waters displayed clear feeding selectivity, favoring dinoflagellates over other types of phytoplankton. Cryptophytes were also positively selected by mesozooplankton at the coastal site, but not at the estuarine site, and cyanobacteria and green algae were not efficiently ingested. The observed mesozooplankton feeding selectivity and its spatial and temporal variations are likely the effects of a combination of different factors, including the composition of predators and the size and quality of the prey.

Acknowledgements. We thank Candy Lee for logistic and laboratorial assistance and 2 anonymous reviewers for their helpful comments. This research is supported by the Hong Kong RGC (GRF grants HKUST6414/06M and 661407) to H.L.

\section{LITERATURE CITED}

Atkinson A (1996) Subantarctic copepods in an oceanic, low chlorophyll environment: ciliate predation, food selectivity and impact on prey populations. Mar Ecol Prog Ser 130: 85-96

Barreiro A, Guisande C, Frangópulos M, González-Fernández A and others (2006) Feeding strategies of the copepod Acartia clausi on single and mixed diets of toxic and nontoxic strains of the dinoflagellate Alexandrium minutum. Mar Ecol Prog Ser 316:115-125
Calbet A (2001) Mesozooplankton grazing effect on primary production: a global comparative analysis in marine ecosystems. Limnol Oceanogr 46:1824-1830

Calbet A, Landry MR (1999) Mesozooplankton influences on the microbial food web: Direct and indirect trophic interactions in the oligotrophic open ocean. Limnol Oceanogr 44:1370-1380

Calbet A, Landry MR (2004) Phytoplankton growth, microzooplankton grazing, and carbon cycling in marine systems. Limnol Oceanogr 49:51-57

Chen B, Liu H, Landry MR, Chen M and others (2009) Estuarine nutrient loading affects phytoplankton growth and microzooplankton grazing at two contrasting sites in Hong Kong coastal waters. Mar Ecol Prog Ser 379:77-90

Chesson J (1978) Measuring preference in selective feeding. Ecology 59:211-215

Cushing DH (1989) A difference in structure between ecosystems in strongly stratified waters and those that are only weakly stratified. J Plankton Res 11:1-3

> Dagg MJ, Strom S, Liu H (2009) High feeding rates on large particles by Neocalanus flemingeri and $N$. plumchrus, and consequences for phytoplankton community structure in the subarctic Pacific Ocean. Deep Sea Res I 56:716-726

Dam HG, Colin SP (2005) Prorocentrum minimum (clone Exuv) is nutritionally insufficient, but not toxic to the copepod Acartia tonsa. Harmful Algae 4:575-584

DeMott WR (1989) Optimal foraging theory as a predictor of chemically mediated food selection by suspension-feeding copepods. Limnol Oceanogr 34:140-154

Dutz J (1998) Repression of fecundity in the neritic copepod Acartia clausi exposed to the toxic dinoflagellate Alexandrium lusitanicum: relationship between feeding and egg production. Mar Ecol Prog Ser 175:97-107

Eppley RW, Reid FMH, Strickland JDH (1970) Estimates of phytoplankton crop size, growth rate and primary production. Bull Scripps Inst Oceanogr 17:33-42

Fielding S, Ward P, Pollard RT, Seeyave S and others (2007) Community structure and grazing impact of mesozooplankton during late spring/early summer 2004/2005 in the vicinity of Crozet Islands (Southern Ocean). Deep Sea Res II 54:2106-2125

Frost BW (1972) Effects on size and concentration of food particles on the feeding behaviour of the marine planktonic copepod Calanus finmarchicus. Limnol Oceanogr 17: 805-815

Garibotti IA, Vernet M, Kozlowskiki WA, Ferrario ME (2003) Composition and biomass of phytoplankton assemblages in coastal Atlantic waters: a comparison of chemotaxonomic and microscopic analyses. Mar Ecol Prog Ser 247: $27-42$

Goericke R, Montoya J (1998) Estimating the contribution of microalgal taxa to chlorophyll $a$ in the field - variations of pigment ratios under nutrient- and light-limited growth. Mar Ecol Prog Ser 169:97-112

Harris RP (1996) Feeding ecology of Calanus. Ophelia 44: 85-109

> Harrison PJ, Yin K, Gan J, Liu H, Lee JHW (2008) Physicalbiological coupling in the Pearl River Estuary. Cont Shelf Res 28:1405-1415

Head EJH, Harris LR (1994) Feeding selectivity by copepods grazing on natural mixtures of phytoplankton determined by HPLC analysis of pigment. Mar Ecol Prog Ser 110: $75-83$

> Henriksen P, Riemann B, Kaas H, Sørensen HM, Sørensen HL (2002) Effects of nutrient-limitation and irradiance on marine phytoplankton pigments. J Plankton Res 24: $835-858$ 
Hitchcock GL (1982) A comparative study of the size-dependent organic composition of marine diatoms and dinoflagellates. J Plankton Res 4:363-377

Irigoien X, Harris RP, Verheye HM, Joly P and others (2002) Copepod hatching success in marine ecosystems with high diatom concentrations. Nature 419:387-389

> Irigoien X, Meyer B, Harris R, Harbour D (2004) Using HPLC pigment analysis to investigate phytoplankton taxonomy: the importance of knowing your species. Helgol Mar Res $58: 77-82$

Jeffrey SW, Wright SW (1994) Photosynthetic pigments in the Haptophyceae. In: Green JC, Leadbeater BSC (eds) The haptophyte algae. Syst Assoc Special Vol 51. Clarendon Press, Oxford, p 111-132

Jing H, Liu H, Bird DF, Wong THC, Chen X, Chen B (2010) Composition and seasonal variability of picoeukaryote communities at two subtropical coastal sites with contrasting trophic conditions. J Plankton Res 32:565-573

Jones RH, Flynn KJ (2005) Nutritional status and diet composition affect the value of diatoms as copepod prey. Science 307:1457-1459

Kiørboe T (1993) Turbulence, phytoplankton cell size, and the structure of pelagic food webs. Adv Mar Biol 29:1-71

Kleppel GS (1993) On the diets of calanoid copepods. Mar Ecol Prog Ser 99:183-195

Kleppel GS, Frazel D, Pieper RE, Holliday DV (1988) Natural diets of zooplankton off southern California. Mar Ecol Prog Ser 49:231-241

Landry MR, Gifford DJ, Kirchman DL, Wheeler PA, Monger BC (1993) Direct and indirect effects of grazing by Neocalanus plumchrus on plankton community dynamics in the subarctic Pacific. Prog Oceanogr 32:239-258

Landry MR, Decima M, Simmons MP, Hannides CCS, Daniels E (2008) Mesozooplankton biomass and grazing responses to Cyclone Opal, a subtropical mesoscale eddy. Deep Sea Res II 55:1378-1388

Latasa M (2007) Improving estimations of phytoplankton class abundances using CHEMTAX. Mar Ecol Prog Ser 329: $13-21$

Latasa M, Landry MR, Schlueter L, Bidigare RR (1997) Pigment-specific growth and grazing rates of phytoplankton in the central equatorial Pacific. Limnol Oceanogr 42: 289-298

> Leibold MA, Chase JM, Shurin JB, Downing AL (1997) Species turnover and the regulation of trophic structure. Annu Rev Ecol Syst 28:467-494

Liu H, Dagg MJ (2003) Interactions between nutrients, phytoplankton growth, and micro- and mesozooplankton grazing in the plume of the Mississippi River. Mar Ecol Prog Ser 258:31-42

Liu H, Campbell L, Landry MR, Nolla HA, Brown SL, Constantinou J (1998) Prochlorococcus and Synechococcus growth rates and contributions to production in the Arabian Sea during the 1995 Southwest and Northeast Monsoons. Deep Sea Res II 45:2327-2352

Liu H, Dagg MJ, Strom S (2005a) Grazing by the calanoid copepod Neocalanus cristatus on the microbial foodweb in the coastal Gulf of Alaska. J Plankton Res 27:647-662

Liu H, Dagg MJ, Wu CJ, Chiang KP (2005b) Mesozooplankton consumption of microplankton in the Mississippi River plume, with special emphasis on planktonic ciliates. Mar Ecol Prog Ser 286:133-144

Llewellyn CA, Fishwick JR, Blackford CB (2005) Phytoplankton community assemblage in the English Channel: a comparison using chlorophyll a derived from HPLCCHEMTAX and carbon derived from microscopy cell counts. J Plankton Res 27:103-119
Mackey MD, Macked DJ, Higgins HW, Wright SW (1996) CHEMTAX-a program for estimating class abundances from chemical markers: application to HPLC measurements of phytoplankton. Mar Ecol Prog Ser 144:265-283

> Meyer-Harms B, von Bodungen B (1997) Taxon-specific ingestion rates of natural phytoplankton by calanoid copepods in an estuarine environment (Pomeranian Bight, Baltic Sea) determined by cell counts and HPLC analyses of marker pigments. Mar Ecol Prog Ser 153:181-190

Meyer-Harms B, Irigoien X, Head R, Harris R (1999) Selective feeding on natural phytoplankton by Calanus finmarchicus before, during, and after the 1997 spring bloom in the Norwegian Sea. Limnol Oceanogr 44:154-165

> Miralto A, Barone G, Romano G, Poulet SA and others (1999) The insidious effect of diatoms on copepod reproduction. Nature 402:173-176

Montagnes DJS, Berges JA, Harrison PJ, Taylor FJR (1994) Estimating carbon, nitrogen, protein, and chlorophyll a from volume in marine phytoplankton. Limnol Oceanogr 39:1044-1060

- Moon-van der Staay SY, De Wachter R, Vaulot D (2001) Oceanic 18S rDNA sequences from picoplankton reveal unsuspected eukaryotic diversity. Nature 409:607-610

Nelson JR (1989) Phytoplankton pigments in macrozooplankton feces: variability in carotenoid alterations. Mar Ecol Prog Ser 52:129-144

Not F, Latasa M, Marie D, Cariou T, Vaulot D, Simon N (2004) A single species, Micromonas pusilla (Prasinophyceae), dominates the eukaryotic picoplankton in the western English Channel. Appl Environ Microbiol 70:4064-4072. doi:10.1128/AEM.70.7.4064-4072.2004

> Obayashi Y, Tanoue E (2002) Growth and mortality rates of phytoplankton in the northwestern North Pacific estimated by the dilution method and HPLC pigment analysis. J Exp Mar Biol Ecol 280:33-52

> Prince EK, Lettieri L, McCurdy KJ, Kubanek J (2006) Fitness consequences for copepods feeding on a red tide dinoflagellate: deciphering the effects of nutritional value, toxicity, and feeding behavior. Oecologia 147:479-488

Rodríguez F, Varela M, Zapata M (2002) Phytoplankton assemblages in the Gerlache and Bransfield Straits (Antarctic Peninsula) determined by light microscopy and CHEMTAX analysis of HPLC pigment data. Deep-Sea Res II 49:723-747

Rodríguez F, Chauton M, Johnsen G, Andersen K, Olsen LM, Zapata M (2006) Photoacclimation in phytoplankton: implications for biomass estimates, pigment functionality and chemotaxonomy. Mar Biol 148:963-971

Shin K, Jang MC, Jang PK, Ju SJ, Lee TK, Chang M (2003) Influence of food quality on egg production and viability of the marine planktonic copepod Acartia omorii. Prog Oceanogr 57:265-277

Sommer F, Stibor H, Sommer U, Velimirov B (2000) Grazing by mesozooplankton from Kiel Bight, Baltic Sea, on different sized algae and natural seston size fractions. Mar Ecol Prog Ser 199:43-53

Stevens CJ, Deibel D, Parrish CC (2004) Copepod omnivory in the North Water Polynya (Baffin Bay) during autumn: spatial patterns in lipid composition. Deep-Sea Res I 51: $1637-1658$

Strickland JDH, Parsons TR (1972) A practical handbook of seawater analysis, 2nd edn. Bull Fish Res Board 167: 201-203

Strom SL, Macri EL, Olson MB (2007) Microzooplankton grazing in the coastal Gulf of Alaska: variations in topdown control of phytoplankton. Limnol Oceanogr 52: 1480-1494 
Sun J, Liu D (2003) Geometric models for calculating cell biovolume and surface area for phytoplankton. J Plankton Res 25:1331-1346

Sushchik NN, Gladyshev MI, Makhutova ON, Kalachova GS, Kravchuk ES, Ivanova EA (2004) Associating particulate essential fatty acids of the $\omega 3$ family with phytoplankton species composition in the Siberian reservoir. Freshw Biol 49:1206-1219

Suzuki K, Minami C, Liu H, Saino T (2002a) Temporal and spatial patterns of chemotaxonomic algal pigments in the subarctic Pacific and the Bering Sea during summer 1999. Deep Sea Res II 49:5685-5704

Suzuki K, Tsuda A, Kiyosawa H, Takeda S and others (2002b) Grazing impact of microzooplankton on a diatom bloom in

Editorial responsibility: Matthias Seaman, Oldendorf/Luhe, Germany a mesocosm as estimated by pigment-specific dilution technique. J Exp Mar Biol Ecol 271:99-120

Verity P, Paffenhöfer GA (1996) On assessment of prey ingestion by copepods. J Plankton Res 18:1767-1779

Wong CK, Wong CK (2003) HPLC pigment analysis of marine phytoplankton during a red tide occurrence in Tolo Harbour, Hong Kong. Chemosphere 52:1633-1640

Wright SW, Jeffrey SW (2006) Pigment markers for phytoplankton production. In: Volkman JK (ed) Marine organic matter. The handbook of environmental chemistry Vol 2. Springer-Verlag, Berlin, p 71-104

- Yin K (2003) Influence of monsoons and oceanographic processes on red tides in Hong Kong waters. Mar Ecol Prog Ser 262:27-41

Submitted: July 2, 2009; Accepted: February 19, 2010 Proofs received from author(s): May 2, 2010 